LAGIPOIVA CHERELLE

JACKSON is a Samoan journalist

and an Orator's daughter.

\section{The brutally honest Orator}

The Orator (O Le Tulafale), written and directed by Tusi Tamasese. Apia: Samoa, 2011. $1 \mathrm{hr} 50 \mathrm{~min}$. theoratorfilm.co.nz

OU know why women don't
want to be Orators, because they don't want to show their breasts in public.' This is how Samoan High Chief Tagaloa spoke, squinting through his leathery brown skin framed by a light trim of siga (white hair) as he spoke to Saili, the main actor in the feature film The Orator. ${ }^{1}$

When this was said, my 8-yearold nephew Barry Uelese Sapatu nudged me in the Magik Cinema in Apia and said: 'But aunty, Grandma is an orator, and she doesn't show her breasts in public, or does she?'

Naturally the answer was 'no' but as my mother Vaasiliifiti Moelagi can attest, it isn't an easy task being a female Orator, let alone a very short one. That much was clear in the film by Tusi Tamasese. I watched the film, not just as a journalist, but as a daughter of an Orator,

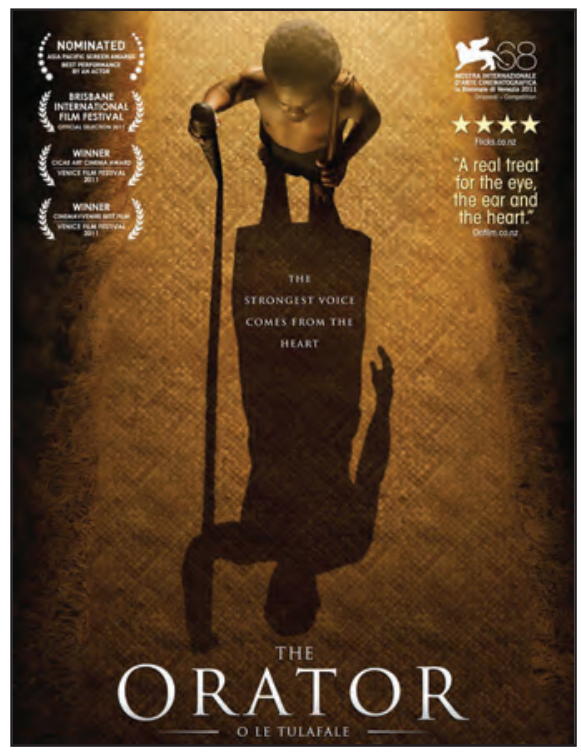

as a girl from Savaii and as a fiercely proud Samoan.Those three factors meant I went into cinema highly sceptical of this New Zealand-made film about Samoa, as I had great doubts that it would be culturally accurate, let alone realistic.

The first scene convinced me, it was the sound of the rain, the mist over the mountains, the colour of the grass and the voice of the boy singing in the plantation that gave me great hope that indeed the film would be true to Samoa.

One hour into it, I was thoroughly impressed.

The film was a little disturbing at first, as it gathers all the sad truths about the Samoan culture and weaves 
them together in extremely aweinspiring cinematography.

But who was I kidding? It was the truth, and it was so accurate, and so beautifully done it was almost painful to watch.

This is by far the best Samoan feature film ever made, and trust me, I have seen them all. If it has a Samoan word in it - even a flash of brown skin, even a short reference to Polynesia - then I have watched it.

The Orator makes no pretence; it doesn't make the Samoan culture look beautiful and admirable; it draws out the violence, the hatred, the slanted hierarchy and ultimately the discriminating nature of our people in a story line that happens in real life.

I can relate to many scenes in that film, from swimming in the village pool to wrapping the dead body of a loved one in a tapa cloth.

I have sat like Litia next to my mother, with a humble fine mat in front of me, while she lays out in metaphors why our fine mat belonged on the coffin of either a great uncle or my dear grandmother.

When Saili, now Leopao, explained in simple words why Vaaiga's body should be returned to him, I cried, because I have seen those arguments in real life.

The accuracy of the cultural representations in The Orator was absolutely astounding and those who ensured the quality of this film must be commended.

The film portrayed the beauty of the Samoan village and landscape, it explored the simplicity of Samoan life, the home and the family but it also drew out some very heavy and dark issues about discrimination, death and hierarchy.

Samoans will be the first to deny the accuracy of this film, but it's important to keep in mind, like any other culture it has its negative extremes.

My mother, an Orator for more than 50 years, enjoyed the film. She said the Oratory, although not extensive, was mostly accurate and made it appealing to those who don't understand the chiefly language.

She enjoyed the part where the Tagaloa took off his ie (skirt). She said it displayed the daring nature of our people.

She liked the fact that the film included stone-throwing fights, a pregnant school girl and an affair in the village, because to her, it's important that those elements of village life are captured.

I agreed. What was portrayed are things that happen in the Samoan culture that are not necessarily talked about; some villages do not see the banishment of a pregnant young woman as a negative thing, in fact the 
Church also ousts the young woman or fines her family if the village does not banish her.

People who look different are teased constantly; if you're dark you are 'black thing'; if you are short you are 'thing that is short'; if you are light-skinned you are a 'fake palagi' and the list goes on.

The Orator is poignant; it forces the audience to contemplate the notso-Paradisal image of Samoa, and ultimately it brings out the natural acting talents of our people and it artistically embraces the reality of the Samoan culture.

\section{Note}

1. Journalist Cherelle Jackson holds the title Lagipoiva from the island of Savai'i where she is the daughter of High Chief and Orator Vaasiliifiti Tauo Moelagi Jackson. This review was originally published on Pacific Media Centre Online.

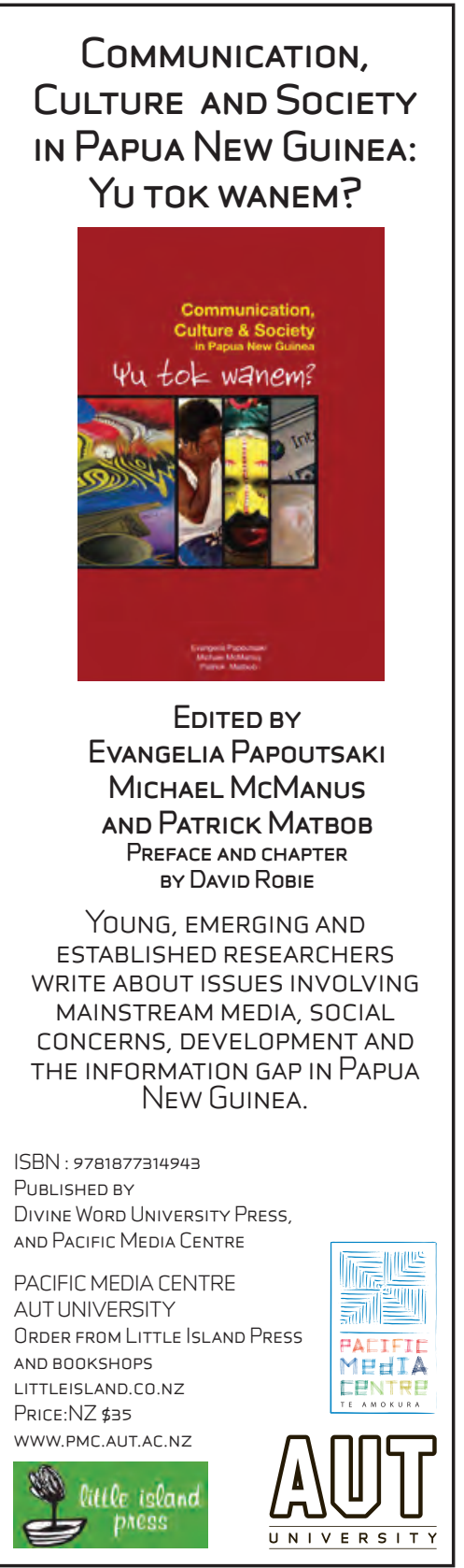

